JMKSP (Jurnal Manajemen, Kepemimpinan, dan Supervisi Pendidikan)

Volume 7 Issue 1 (2022) Page 399-410

ISSN 2614-8021 (Online) 2548-7094 (Print)

\title{
Community Participation in the Adiwiyata Program for Strengthening Character Education of MAN Students in South Kalimantan
}

\section{Eddy Khairani Z1 ${ }^{1}$ Hanafiah $^{1}$, Yosal Iriantara ${ }^{1}$, HR. Supyan Sauri ${ }^{1}$ \\ ${ }^{1}$ Universitas Islam Nusantara Bandung, Indonesia Corresponding Author E-mail: eddy.khairani.z@gmail.com}

Received 2 November 2021; Revised 12 February 2022; Accepted 11 March 2022

Abstract: This study aimed to identify the implementation of adiwiyata policies as an effort to realize environmental education in madrasas. It is to realize environmental education effectively and efficiently. The method is case study method at MAN 1 Tapin and MAN 2 Tapin to find out how to plan, implement, organize, evaluate, support and inhibit factors as well as solutions and future improvement efforts in the Adiwiyata program to strengthen character education of MAN students. The results of this study were the community participation in the Adiwiyata program for strengthening character education for MAN 1 Tapin and MAN 2 Tapin students was carried out with reference to applicable regulations and guidelines, but it had not performed the efforts to strengthen character and the level of community participation.

Keywords: Strengthening Character Education, Community Participation and Adiwiyata Programs

\section{Introduction}

As an educational institution, school is responsible to build childern character. Therefore, the role and contribution of the teacher is very dominant (Sudiami et al., 2019). As an institution, schools have a moral responsibility to educate children to be smart, intelligent, and good characters as expected by every parent (Anugerah Ash-shidiqqi, 2018).

In the begining, education is a conception of ahlaq education, while ahlaq is a gift from God (good morality) and a devil guidance on his promise to God of all 
nature (bad morality) that is always brought by humans every time they are born to this earth (Saputro \& Murdiono, 2020). In other words, the Khaliq creates Mahluq who has Ahlaq (Marini, 2018).

Character formation is driven by understanding, beliefs, habits and mindsets from environment (Hayati et al., 2020). The environment consists of school environment, family environment and social environment (Nauli et al., 2016). Therefore, the formation of character is strongly influenced by many factors, one of which is the environment. If a child is developed and educated well in a good family environment but his social environment is not good, then it will greatly affect him (Adawiah, 2019).

The issue of national character is now becomes the public spotlight. The issues that arise in society such as corruption, violence, sexual crimes, vandalism, mass fights, consumptive economic life, unproductive political life, and have become hot topics of discussion on various occasions. Various solutions to the problem of national character have been proposed, such as regulations, laws, and increased efforts to implement and apply stronger laws (Fatimah, 2019).

The involvement of school community in these various activities will be able to increase awareness and habituation of a more meaningful life in forming the attitudes of students and school members towards the values reflected in everyday life at school (Hatmansyah et al., 2021). It is manifested in daily attitudes and behavior at, school, home or in the neighborhood where they live (Taufik Rahman et al., 2021).

Through strengthening character education, it is hoped that there will be synergy in building education between teachers, parents and the government with various activities, one of which is participation in the Adiwiyata School program. In running the adiwiyata program, it is expected that every school member will be involved and active in school activities towards a healthy environment and avoid negative environmental impacts (Rahman et al., 2021). The implementation of adiwiyata schools includes three kinds, namely first, the curricular field, environmental learning is carried out in an integrated manner with existing subjects so that teachers must be good at making learning designs with the environment. Second, the extracurricular field which leads to the formation of student awareness of environmental conservation through environmental education activities and environmental work competitions (Fadillah et al., 2021). Third, in the field of school environmental management, the first is the use and arrangement of school land into natural laboratories such as gardens and 
medicinal plants, invitations to save energy and water, recycle waste, manage the social environment in the form of habituation of positive real behaviors. including discipline, cooperation, caring, honesty, and respect for local wisdom (Tambrin et al., 2021).

Regarding the problems and obstacles in implementing character education strengthening through community participation in the Adiwiyata program in madrasas, the results of Firdao research (2017) states that the ability of schools to develop collaboration and community involvement in KDP still faces various obstacles and can be categorized as not optimal, although in general the community is enthusiastic about welcoming the KDP program, and has the willingness to actively participate in the success of the KDP program. It happens because communication patterns that have not been established effectively found an activity design or implementation design that fits the needs of the school (interests, talents, abilities and creativity of the school as well as local wisdom in the school environment.

Based on the description, it can be concluded that the involvement of the school community, both teachers and parents of students in strengthening character education is very necessary. Through harmonization of taste, thought, and exercise with the support of involving all elements of the school community and parents of students and cooperation between schools, families, and communities. Through the heart, students are expected to have deep spirituality, faith and piety to God Almighty. Through this sense, students are expected to have moral integrity, a sense of art and culture.

Adiwiyata as a school program aims to create good conditions for schools to be a place of learning and to raise awareness for school residents, both educators, education staff, students and the community around the school as the effort to encourage environmental conservation and sustainable development that can ultimately realize environmentally friendly and cultured school.

The school community is involved in school management that includes the entire planning, implementation and evaluation process according to responsibilities and roles. The involvement of school residents in the implementation of the Adiwiyata program is an important point for the success of the program. School residents in this case are all school components that include principals, teachers, employees, employees and even canteen employees that are required to play an active role in creating a culture of caring the environment. 
Based on this reason, the author is interested in conducting research related to Strengthening Character Education through the participation of all school members, both students themselves, teachers and even parents of students in various Adiwiyata school program activities both in the form of participation, participation activities and level of participation. MAN 1 Tapin and MAN 2 Tapin are the schools that are concerned with developing a school program that cares the environment (Adiwiyata School).

By this research, researchers hope to be able to explore and understand the implementation of adiwiyata policies as an effort to realize environmental education in madrasas so they can implement adiwiyata policies to realize environmental education effectively and efficiently.

\section{Methods}

The method used in this research is the case study method. In this research the author used several data collection techniques that can be seen in table 1 below.

Table 1. Data Collection Grids and Instruments: community participation in the Adiwiyata program to strengthen student character education

\begin{tabular}{|c|c|c|c|c|c|c|}
\hline \multirow[t]{2}{*}{ No } & \multirow[t]{2}{*}{$\begin{array}{l}\text { Research } \\
\text { Question }\end{array}$} & \multirow[t]{2}{*}{ Indicator/Material Needed } & \multirow[t]{2}{*}{ Data Source } & \multicolumn{3}{|c|}{$\begin{array}{c}\text { Data Collection } \\
\text { Method }\end{array}$} \\
\hline & & & & $\mathbf{O}$ & $\mathbf{W}$ & SD \\
\hline 1 & $\begin{array}{l}\text { Community } \\
\text { participation } \\
\text { planning in } \\
\text { Adiwiyata } \\
\text { program to } \\
\text { strengthen } \\
\text { character } \\
\text { education for } \\
\text { MAN students }\end{array}$ & $\begin{array}{l}\text { a. } \begin{array}{l}\text { Determination of the } \\
\text { objectives of the adiwiyata } \\
\text { program }\end{array} \\
\text { b. } \begin{array}{l}\text { Determination of the } \\
\text { strategy for achieving the } \\
\text { goals of the adiwiyata } \\
\text { program }\end{array} \\
\text { c. Determination of } \\
\text { d. Determination of } \\
\text { adiwiyata program } \\
\text { procedures } \\
\text { e. Determination of method } \\
\text { f. Determination of } \\
\text { adiwiyata program budget } \\
\text { system standards needed } \\
\text { to achieve adiwiyata goals }\end{array}$ & $\begin{array}{ll}\text { a. } & \text { Madrasah } \\
\text { Committee } \\
\text { b. Head of } \\
\text { c. Madrasah } \\
\text { c. Deputy Head } \\
\text { of Madrasah } \\
\text { d. Teacher }\end{array}$ & $\sqrt{ }$ & $\sqrt{ }$ & $\sqrt{ }$ \\
\hline 2 & Organizing & a. Grouping the work of & a. Madrasah & $\sqrt{ }$ & $\sqrt{ }$ & $\sqrt{ }$ \\
\hline
\end{tabular}




\begin{tabular}{|c|c|c|c|c|c|c|}
\hline & $\begin{array}{l}\text { community } \\
\text { participation in } \\
\text { the adiwiyata } \\
\text { program to } \\
\text { strengthen } \\
\text { character } \\
\text { education for } \\
\text { MAN students }\end{array}$ & $\begin{array}{ll}\text { b. } & \text { adiwiyata program } \\
\text { Division of adiwiyata } \\
\text { program tasks } \\
\text { c. } & \text { Organizational } \\
& \text { environment (availability } \\
\text { of madrasah resources) } \\
\text { adiwiyata program }\end{array}$ & $\begin{array}{ll}\text { b. } & \text { Committee } \\
& \text { Head of } \\
\text { Madrasah } \\
\text { c. } & \text { Deputy Head } \\
& \text { of Madrasah } \\
\text { d. } & \text { Teacher }\end{array}$ & & & \\
\hline 3 & $\begin{array}{l}\text { Implementation of } \\
\text { community } \\
\text { participation in } \\
\text { the adiwiyata } \\
\text { program to } \\
\text { strengthen } \\
\text { character } \\
\text { education for } \\
\text { MAN students }\end{array}$ & $\begin{array}{l}\text { a. Availability of supporting } \\
\text { resources for the } \\
\text { Adiwiyata program } \\
\text { b. The form of community } \\
\text { involvement in the } \\
\text { Adiwiyata program } \\
\text { c. Results of community } \\
\text { involvement in the } \\
\text { adiwiyata program }\end{array}$ & $\begin{array}{ll}\text { a. } & \text { Madrasah } \\
& \text { Committee } \\
\text { b. } & \text { Head of } \\
& \text { Madrasah } \\
\text { c. } & \begin{array}{l}\text { Deputy Head } \\
\text { of Madrasah }\end{array} \\
\text { d. } & \text { Teacher }\end{array}$ & $\sqrt{ }$ & $\sqrt{ }$ & $\sqrt{ }$ \\
\hline 4 & $\begin{array}{l}\text { Community } \\
\text { evaluation in the } \\
\text { adiwiyata } \\
\text { program to } \\
\text { strengthen } \\
\text { character } \\
\text { education for } \\
\text { MAN students }\end{array}$ & $\begin{array}{l}\text { a. The effectiveness of } \\
\text { community participation } \\
\text { in the adiwiyta program } \\
\text { b. Adequacy, namely the } \\
\text { extent to the results } \\
\text { obtained can solve student } \\
\text { character problems } \\
\text { c. Implementation, the costs } \\
\text { and benefits can be } \\
\text { channeled in } \\
\text { strengthening student } \\
\text { character education. }\end{array}$ & $\begin{array}{ll}\text { a. } & \text { Madrasah } \\
& \text { Committee } \\
\text { b. } & \text { Head of } \\
& \text { Madrasah } \\
\text { c. } & \begin{array}{l}\text { Deputy Head } \\
\text { of Madrasah }\end{array} \\
\text { d. } & \text { Teacher }\end{array}$ & $\sqrt{ }$ & $\sqrt{ }$ & $\sqrt{ }$ \\
\hline 5 & $\begin{array}{l}\text { The problem of } \\
\text { community } \\
\text { participation in } \\
\text { the Adiwiyata } \\
\text { program to } \\
\text { strengthen the } \\
\text { character } \\
\text { education of } \\
\text { MAN students }\end{array}$ & $\begin{array}{l}\text { The problem of community } \\
\text { participation in Adiwiyata } \\
\text { program to strengthen the } \\
\text { character education of MAN } \\
\text { students }\end{array}$ & $\begin{array}{ll}\text { a. } & \text { Madrasah } \\
& \text { Committee } \\
\text { b. } & \text { Head of } \\
& \text { Madrasah } \\
\text { c. } & \begin{array}{l}\text { Deputy Head } \\
\text { of Madrasah }\end{array} \\
\text { d. } & \text { Teacher }\end{array}$ & $\sqrt{ }$ & $\sqrt{ }$ & $\sqrt{ }$ \\
\hline 6 & $\begin{array}{l}\text { Solutions to } \\
\text { overcome the }\end{array}$ & $\begin{array}{l}\text { Strategic efforts to overcome } \\
\text { the problem of community }\end{array}$ & $\begin{array}{ll}\text { a. } & \text { Madrasah } \\
& \text { Committee } \\
\end{array}$ & $\sqrt{ }$ & $\sqrt{ }$ & $\sqrt{ }$ \\
\hline
\end{tabular}




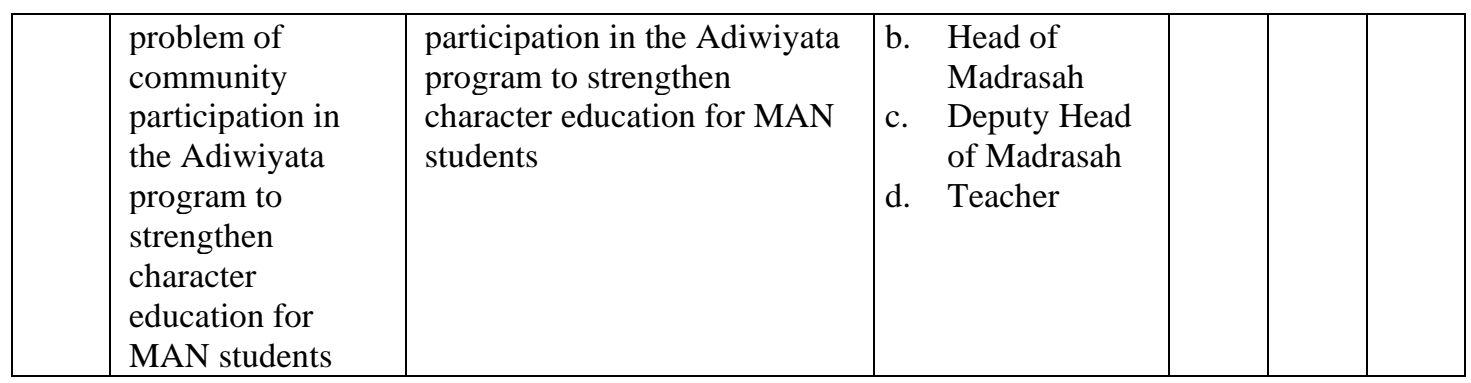

Note : O (Observation), W (Interview ) SD (Documentation Study)

\section{Results and Discussion}

\section{Community Participation Planning in the Adiwiyata Program for Strengthening Character Education of MAN Students}

The formulation of community participation planning in the Adiwiyata program to strengthen character education of MAN 1 Tapin and MAN 2 Tapin students formulates and sets the goals of the Adiwiyata program by gathering all stakeholders for deliberating and building commitment and understanding of the Adiwiyata program. Then it formed the Adiwiyata and Pokja teams to carry out their respective tasks according to the objectives. The madrasah also determines the strategy for achieving the goals of the Adiwiyata program by studying and understanding the components of the Adiwiyata assessment carried out by each Pokja and all madrasa residents.

The formulation and determination of Adiwiyata goals program by reviewing the objectives of the Adiwiyata program through environmental subjects. The madrasah determines the strategy for achieving the goals of the Adiwiyata program by setting an action plan by looking at the components and standards of Adiwiyata as success measurement. The formulation of the Adiwiyata program policy was carried out through official meetings with all madrasah stakeholders and consultations with the Tapin District Environmental Service. The madrasa has established the Adiwiyata program procedure in strengthening student character education by inputting learning materials in the curriculum for the students, namely through the Environmental Subjects (LH). The determination of the method of implementing the Adiwiyata program is to use an environment-based learning method. The madrasah determines the budget system for the Adiwiyata program from DIPA, Madrasah Committee, and others. The standards needed to 
achieve Adiwiyata goals are the fulfillment of the indicators in the Adiwiyata assessment.

The madrasa had established procedures for Adiwiyata program in strengthening student character education by linking learning materials with the LH (Environment). The madrasa determines the method of Adiwiyata program implementation through the development of environmental-based learning methods. The madrasah determines the budget system for the Adiwiyata program through the DIPA and BOS budgets. The standard needed to achieve Adiwiyata goals in the fulfillment of the Adiwiyata assessment indicator components.

The madrasah determines the method of implementing the adiwiyata program through coordination with the Tapin district environmental office. The madrasah determines the budget system for the Adiwiyata program through coordination with the madrasa treasurer and the madrasa committee. The standard needed to achieve Adiwiyata goals with the coordination with the Tapin Environmental Agency.

The madrasah determines the strategy for achieving the goals of the Adiwiyata program by studying the indicators/components of the Adiwiyata assessment. The madrasah formulates the Adiwiyata program policy through meetings/deliberation of all madrasa residents. The madrasa has established procedures for the Adiwiyata program in strengthening student character education by linking learning materials with the environment. The madrasah determines the method of implementing the Adiwiyata program through the development of environmental-based learning methods.

\section{Organizing Community Participation in the Adiwiyata Program for Strengthening Character Education of MAN Students}

The madrasah grouped the work of the Adiwiyata program by involving homeroom teachers and students. Madrasahs perform the division of tasks for the Adiwiyata program through their respective Pokja heads. The madrasah organizes the organizational environment (availability of madrasa resources) for the Adiwiyata program through the preparation of the Pokja that must be in accordance with the respective madrasa environment.

The madrasah grouped the work of the Adiwiyata program by involving students with the Adiwiyata Working Group. The madrasah divides the tasks of Adiwiyata program through the heads of each Pokja. The madrasah organizes the organizational environment (availability of madrasa resources) for the Adiwiyata 
program, the preparation of the Pokja is adjusted to the environmental conditions of the madrasa.

Organizing community participation in the adiwiyata program for strengthening the character education of MAN students should maximize the role and function of each component in implementing adiwiyata program including the components of the madrasa principal, vice principals, teacher councils, students, organizers of the division of tasks within the organization that will influence each other and affect the community participation organization in the Adiwiyata program to strengthen the character education of students. If one component does not work properly, then components will be harmed.

\section{Implementation of Community Participation in the Adiwiyata Program for Strengthening Character Education of MAN Students}

Community participation in improving the quality of madrasa is a historical fact. Madrasa as the front line in educational organizations have become pioneers in implementing the policies in madrasa program. The idea of establishing a madrasa is an idea from the community, carried out by the community and intended for the community. By implementing the Adiwiyata program, it will create school residents, especially students who care and are environmentally cultured, as well as to support and realize human resources that have national character for economic, social and environmental development in achieving sustainable development in the region.

\section{Evaluation of Community Participation in the Adiwiyata Program for Strengthening Character Education of MAN Students}

Program evaluation is intended to provide input, study and consideration in determining the program that is worth continuing or discontinuing. Under these conditions, the term of program evaluation has become commonplace in educational institutions. Environmental education is very important to school residents to improve the environment and reduce environmental damage in a better future, one of the behaviors that need to be developed for the young generation is environmental care and responsibility. Environmental education is an effort to provide environmental knowledge among school students.

The success of a program makes the distinct advantage for the agency that implements it. From the success of the program, the evaluation is now carried out to find out the progressing of the program. Furthermoe, by conducting an 
evaluation, researchers can understand the details of the program itself, such as planning to program sustainability.

\section{The Problem of Community Participation in the Adiwiyata Program for Strengthening Character Education of MAN Students}

The problem of community participation in the Adiwiyata program for strengthening character education for MAN students is related to the efforts to form and strengthen student character. Related to strengthening character education, it is interpreted as the responsibility of school to strengthen the character of students through harmonization of heart, taste, thought, and sports activities with the involvement of cooperation between education units, families, and the community as part of the National Mental Revolution Movement (GNRM). Regarding the implementation, character strengthening leads to five main values such as : religiosity, nationalism, independence, mutual cooperation, and integrity in every aspect of life. The problem of achieving the character values of religiosity, nationalism, independence, mutual cooperation, and integrity had not been fully achieved maximally.

The efforts to create adiwiyata nuance by each school can be synergized with the program that has been implemented as strengthening character education in each school. The implementation of strengthening character education is essentially an effort to build and strengthen positive attitudes in all students as the future generation of the natio life.

Solutions to Overcoming the Problem of Community Participation in the Adiwiyata Program for Strengthening Character Education of MAN Students

Various forms of the implementation had been pursued by schools such as the form of exemplary carried out by teachers so that students imitate the behavior of good and positive teachers. One form of teacher example is when the teacher provides assistance on clean Fridays, the teacher did not only direct but the teacher also directly involved with students such as giving examples of caring for plants, watering plants, cutting plants that damaged and replaced with new ones, sorting organic waste and non-organic, washing hands after doing clean Friday activities using soap in the sink.

Participatory-based habituation in Adiwiyata program implementation at MAN 1 Tapin and MAN 2 Tapin was realized through the implementation of 
collaborative activities with external parties involved in the implementation of the Adiwiyata program. One of the collaborations carried out was by conducting training on plants with the Department of Environment in Tapin district. The collaboration had been carried out between the two madrasas.

It showed the effort in implementing the Adiwiyata program became adjusted to one of the indicator of the Ministry of Environment in establishing partnerships in the context of environmental management and protection with various parties (Mahendrartha et al, 2020).

\section{Conclusion}

Community participation planning in strengthening character education in the adiwiyata program can be seen through the role of the madrasa committee in supporting the strengthening of character education in adiwiyata program. However, the community participation form in strengthening character education in the Adiwiyata program had not fully touched the effort to instill the character values of caring the school environment. The organizers of community participation activities in strengthening character education in the adiwiyata program were made and compiled simultaneously with the madrasah in adiwiyata program. Community participation activities in strengthening character education in the Adiwiyata program were still focused on material assistance and funding in order to support strengthening character education in the Adiwiyata program, but had not yet targeted the strengthening of character education for students.

The implementation of community participation in strengthening character education in the Adiwiyata program in madrasas met the Adiwiyata program assessment aspects but the results of community participation in strengthening character education in the Adiwiyata program at madrasas have not targeted the actual strengthening of character education. The character of caring for the environment is a character that must be implemented for madrasas at every level of education. All madrasa residents must have the attitude of caring for the environment by improving the quality of the environment, increasing awareness of madrasa residents about the importance of caring for the environment and having initiatives to prevent environmental damage. Evaluation of community participation in the Adiwiyata program for strengthening the character education of MAN students had been carried out based on the Adiwiyata Madrasa assessment system, but it had not been fully maximized in strengthening the character values in school environment. Supporting and inhibiting factors as well 
as strategies as an effort to participate in the Adiwiyata program to strengthen the character education of MAN students, including the formation of environmental care characters that are applied in madrasas, starting with socialization, there are many ways in socializing madrasa residents related to For example, Adiwiyata mentoring teachers guide subject teachers to incorporate environmental activities in the form of theory and practice into the RPP (Learning Implementation Plan) and as a form of a healthy and sustainable living environment in the madrasa environment, starting with the existence of environmental care characters that are implemented hrough actions. Solutions and future improvement efforts in community participation for Adiwiyata program is to strengthen the character education of MAN students. It can be done by formation and development of the character of students, especially the character of caring for the environment that is carried out through environmental education learning. The characters that will be formed and developed from the learning outcomes of Environmental Education need to be monitored and evaluated so that the goals can be realized.

\section{Acknowledgment}

Thanks to Rector Universitas Islam Nusantara, Bandung and all collagues who have contributed to the completion of this study.

\section{References}

Adawiah, R. (2019). Implementation of Adiwiyata Program to Build Environmental Awareness. Journal of Wetlands Environmental Management, 7(2), 106. https://doi.org/10.20527/jwem.v7i2.196

Anugerah Ash-shidiqqi, E. (2018). The Analysis of Character Education in Indonesia. International Journal of Humanities, Art and Social Studies (IJHAS), 3(4), 39-46.

Fadillah, H., Trisnamansyah, S., Insan, H. S., \& Sauri, R. S. (2021). Strategy of Integrated Salaf Curriculum in Madrasah Aliyah to Improve the Graduates'

Quality. Journal of Education Research and Evaluation, 5(4), 656-663.

Fatimah, A. A. and S. (2019). Implementation of Strengthening Values of Nationalism in Character Education Through History Learningin Public

Senior High School 1 Sungai Penuh. International Journal of Educational Dynamics, 1(2), 116-124.

Hatmansyah, Wasliman, I., Insan, H. S., \& Hanafiah. (2021). Leadership Strategies in Improving Higher Education Graduates' Competitiveness. 
International Journal of Educational Review, 4(1), 1-2.

Hayati, F. N., Suyatno, S., \& Susatya, E. (2020). Strengthening of Religious

Character Education Based on School Culture in the Indonesian Secondary

School. The European Educational Researcher, 3(3), 87-100.

Mahendrartha, A., Tobari, T., \& Tabula, R. V. (2020). Adiwiyata-Based School

Management in Indonesia. Journal of Social Work and Science

Education, 1(1), 1-7. https://doi.org/10.52690/jswse.v1i1.4

Marini, A. (2018). Implementation of Character Building at Elementary Schools :

Cases of Indonesia. Proceeding International Conference, 1(1), 60-71.

Nauli, P., Mario, J., Siagian, S., \& Hutapea, T. A. (2016). Development Character

Education Model In Unimed Based Six Characters For Enhancing. 1st

Annual International Seminar on Transformative Education and Educational

Leadership (AISTEEL), 169-179.

Rahman, A., Wasliman, I., \& Hanafiah, H. (2021). The Implementation of

Strengthening Character Education Program through Scouts Extracurricular

Activities in Islamic Senior High School 1 Pulang Pisau and Islamic. Journal of Education Research and Evaluation, 5(4), 633-644.

Saputro, J. D., \& Murdiono, M. (2020). Implementation of Character Education through a Holistic Approach to Senior High School Students. International Journal of Multicultural and Multireligious Understanding, 7(11), 460-470.

Sudiami, D., Martitah, M., \& Subagyo, S. (2019). Internalization of Social Value Based on Character Education Strengthening through Scouting Extracurricular Activities in Public Junior High School 1 Batang. Journal of Educational Social Studies, 8(274), 68-76.

Tambrin, M., Wasliman, I., \& Hanafiah, H. (2021). Implementation and Evaluation of Teachers' Performance Supervision at Madrasah Aliyah (Islamic Senior High School), Journal of Education Research and Evaluation, 5(4), 645-655.

Taufik Rahman, Wasliman, I., Muttaqien, K., \& Sauri, R. S. (2021). Accreditation Policies Implementation to Improve Performance Quality in Madrasah. International Journal of Educational Review, 3(2), 6. 